\title{
Pathological response and clinical outcomes in operable triple-negative breast cancer with cisplatin added to standard neoadjuvant chemotherapy
}

\author{
Patologická odpoved'a klinické výsledky při léčbě operabilního \\ triple negativního karcinomu prsu cisplatinou přidanou \\ k standardní neoadjuvantní chemoterapii
}

Georgy J.T. ${ }^{1}$, Singh A. ${ }^{1}$, John A.O. ${ }^{1}$, Joel A. ${ }^{1}$, Andrews A.G. ${ }^{1}$, Thumaty D.B. ${ }^{1}$, Rebekah G. ${ }^{2}$, Sigamani E. ${ }^{3}$, Chandramohan J. ${ }^{3}$, Manipadam M.T. ${ }^{3}$, Cherian A.J. ${ }^{4}$, Abraham D.T. ${ }^{4}$, Paul M.J. ${ }^{4}$, Balakrishnan R. ${ }^{5}$, Backianathan S. ${ }^{5}$, Chacko R.T. ${ }^{1}$

\begin{abstract}
'Department of Medical Oncology, Christian Medical College Vellore, Tamil Nadu, India
2 Department of Biostatistics, Christian Medical College Vellore, Tamil Nadu, India

Department of Pathology, Christian Medical College Vellore, Tamil Nadu, India

${ }^{4}$ Department of Endocrine Surgery, Christian Medical College Vellore, Tamil Nadu, India

${ }^{5}$ Department of Radiation Therapy, Christian Medical College Vellore, Tamil Nadu, India
\end{abstract}

\begin{abstract}
Summary
Background: Response to neoadjuvant chemotherapy is associated with improved outcomes for patients with triple negative breast cancer (TNBC). Patients with residual disease are at increased risk of relapse and death from breast cancer. In this retrospective study, we aimed to evaluate the efficacy and safety of cisplatin added to standard neoadjuvant chemotherapy for locally advanced TNBC. Materials and methods: All TNBC treated with neoadjuvant cisplatin $60 \mathrm{mg} / \mathrm{m}^{2}$ once in 3 weeks with weekly paclitaxel for 12 weeks, following 8 weeks of dose-dense epirubicin $90 \mathrm{mg} / \mathrm{m}^{2}$ or doxorubicin $60 \mathrm{mg} / \mathrm{m}^{2}$ with cyclophosphamide $600 \mathrm{mg} / \mathrm{m}^{2}$ were analyzed retrospectively. The data related to pathological complete response, adherence to planned therapy, disease-free survival and overall survival were collected. Results: Eighty-three patients were included, of whom $80 \%$ had stage III disease. Pathological complete response in both breast (T0/Tis) and axilla(N0) was observed in $48.1 \%$ of patients. Miller Payne grade 5 pathological response in the breast was seen in $61 \%$ of patients. Good partial responses (Miller Payne grades 3,4 ) were observed in $32.5 \%$ of patients. The remaining $6.5 \%$ were poor responders. Seventy-seven patients underwent surgery. The disease-free survival at 1 and 3 years for those who had a pathological complete response was $96.7 \%$ and $77.6 \%$, respectively, and $92.3 \%$ and $62.7 \%$ for those who did not, respectively. The predominant adverse events were hematological, with anemia being the most common one. Conclusion: The addition of cisplatin to neoadjuvant chemotherapy with anthracycline and taxane in TNBC was tolerable and produced a high rate of pathological complete response. Cisplatin added to standard chemotherapy in patients with locally advanced TNBC could improve clinical outcomes.
\end{abstract}

Key words

triple negative breast cancer - cisplatin - neoadjuvant chemotherapy - pathological complete response - residual cancer burden
The authors declare they have no potential conflicts of interest concerning drugs, products, or services used in the study.

Autoři deklarují, že $v$ souvislosti $s$ predmětem studie nemaji žádné komerční zájmy.

The Editorial Board declares that the manuscript met the ICMJE recommendation for biomedical papers.

Redakční rada potvrzuje, že rukopis práce splnil ICMJE kritéria pro publikace zasilané do biomedicínských časopisů.

$\Xi^{\circ}$

Ashish Singh, MD, Associate Professor Department of Medical Oncology, Christian Medical College and Hospital

IDA Scudder Rd

Vellore,

Tamil Nadu 632004

India

e-mail: todrashish@gmail.com

Submitted/Obdrženo: 12. 9. 2020 Accepted/Přijato/: 30. 9. 2020 


\begin{abstract}
Souhrn
Východiska: U pacientek s triple negativním karcinomem prsu (triple negative breast cancer - TNBC) je odpověd' na neoadjuvantní chemoterapii spojena s lepšími výsledky. U pacientek s reziduální nemocí je vyšší riziko relapsu a úmrtí na karcinom prsu. Cílem této retrospektivní studie bylo zhodnotit účinnost a bezpečnost cisplatiny přidané k standardní neoadjuvantní chemoterapii při lokálně pokročilém TNBC. Materiál a metody: Retrospektivně byly analyzovány všechny TNBC léčené neoadjuvantní cisplatinou v dávce $60 \mathrm{mg} / \mathrm{m}^{2}$ jednou za 3 týdny s paklitaxelem podávaným 1× týdně po dobu 12 týdnů a poté „dose-dense“ epirubicinem v dávce $90 \mathrm{mg} / \mathrm{m}^{2}$ nebo doxorubicinem v dávce $60 \mathrm{mg} / \mathrm{m}^{2} \mathrm{~s} \mathrm{cyklofosfamidem}$ v dávce $600 \mathrm{mg} / \mathrm{m}^{2}$. Byly shromažd’ovány údaje týkající se patologické kompletní odpovědi, dodržování plánované terapie, přežití bez nemoci a celkového přežití. Výsledky: Do studie bylo zahrnuto 83 pacientek, z nichž 80 \% mělo onemocnění stadia III. Patologická kompletní odpověd' jak v prsu (T0/Tis) tak axile (N0) byla pozorována u 48,1 \% pacientek. Patologická odpověd'stupně 5 dle Millera a Payna v prsu byla pozorována u 61 \% pacientek. Dobrá částečná odpověd' (stupeň 3 nebo 4 dle Millera a Payna) byla pozorována u 32,5\% pacientek. U zbývajících 6,5 \% byla odpověd' špatná. Operaci podstoupilo 77 pacientek. Přežití bez nemoci bylo u pacientek s patologickou kompletní odpovědí 96,7 \% za 1 rok a 77,6 \% za 3 roky a u pacientek bez patologické kompletní odpovědi 92,3\% za 1 rok a 62,7 \% za 3 roky. Nejčastější nežádoucí účinky byly hematologické s převládající anemií. Závěr: Přídavek cisplatiny k neoadjuvantní chemoterapii s antracyklinem a taxanem při léčbě TNBC byl dobře snášen a vedl $\mathrm{k}$ vysokému podílu patologické kompletní odpovědi. Př́ídavek cisplatiny $\mathrm{k}$ standardní chemoterapii u pacientek s lokálně pokročilým TNBC pravděpodobně zlepšil klinické výsledky.
\end{abstract}

\title{
Klíčová slova
}

triple negativní karcinom prsu - cisplatina - neoadjuvantní chemoterapie - patologická kompletní odpoved' - reziduální nádorová zátěž

\section{Introduction}

Breast cancer is the most common cancer among women in India, with 162,468 new cases diagnosed in 2018 [1]. The prevalence of triple-negative breast cancer (TNBC) is higher in the Indian subcontinent, due to a more substantial proportion of younger women (peak age between 45 and 49 years) presenting with this disease as compared to Western countries $[2,3]$. Recent estimates reported TNBC to be $31 \%$ of all breast cancers diagnosed in India [4,5]. A retrospective study found the proportion of TNBC to be $22.2 \%$ among breast cancer patients presenting to our institution [6]. In comparison, the proportion of TNBC in cohorts from Western literature is $15-24 \%[7,8]$. It is a heterogeneous and poorly understood disease that has poor outcomes as compared to the other subtypes of breast cancer. Recent advances in molecular classification have provided some insight into the complex nature of this cancer; however, clinically meaningful results are yet to materialize from this new understanding [9].

The 5-year age-standardized net survival for breast cancer in India between 2005 and 2009 was $60.4 \%(95 \% \mathrm{Cl} 46.5-$ 74.3\%) [10]. A long term (eight-year) follow up of 148 triple-negative breast cancer patients in India showed the disease-free survival and overall survival of $58 \%$ and $75 \%$, respectively [11]. Although the treatment landscape of this disease is changing with the ad- vent of poly (ADP-ribose) phosphate (PARP) inhibitors and immunotherapy, these therapies have not yet made any impact in non-metastatic disease; further, they remain out of reach of most patients in India due to the high cost involved.

Achieving pathological complete response ( $p C R$ ) at the end of neoadjuvant therapy is used as a surrogate endpoint, as it has been shown to predict better outcomes in triple-negative breast cancer [12]. In a pooled analysis, the pCR rates achieved with standard anthracycline and taxane-based chemotherapy in triple-negative breast cancer ranged from $31 \%$ to $33.6 \%[12,13]$.

The use of platinum in triple-negative breast cancer has been shown to increase $\mathrm{pCR}$ rates, with small randomized trials reporting improved $\mathrm{pCR}$ rates in the range of $35-65 \%$ [14-19]. Carboplatin has been the preferred agent at many centers over cisplatin due to its superior tolerability profile [20]. Previous studies have shown that weekly administration of carboplatin and paclitaxel in a dose-dense schedule produces high rates of neutropenia and anemia [14,21]. Cisplatin being less myelotoxic than carboplatin could mitigate the added hematologic toxicity that is common with weekly administration of paclitaxel and thus increase treatment compliance and consequently pCR [22]. The pathological complete response rates with the addition of cisplatin in cohorts of 41,74 , and 52 patients were 65,62 , and $44 \%$, respectively $[17,19,23]$. A retrospective study comparing carboplatin and cisplatin in locally advanced TNBC showed a possible overall and disease-free survival advantage with the use of the latter [18].

There is a paucity of data on the effectiveness of utilizing cisplatin in combination with anthracyclines and taxanes in neoadjuvant therapy of triple-negative breast cancer, especially in locally advanced disease. This retrospective cohort study was carried out to evaluate the efficacy and safety of a neoadjuvant regimen of cisplatin used in combination with anthracycline and taxanes.

\section{Materials and Methods}

Design and patient selection

This retrospective study was undertaken in a 2,800-bed, university-affiliated, private, teaching hospital in South India. The medical records of consecutive adult patients (age $>16$ years), treated in the Medical Oncology Department from April 2015 to June 2019 with histologically confirmed invasive breast carcinoma, were reviewed. The inclusion criteria were non-metastatic disease, triple-negative receptor status $(<1 \%$ tumour cells positive for estrogen and progesterone receptors and Her2/neu immunohistochemistry score of 0 or $1+$ ), good performance status by Eastern Cooperative Oncology Group (ECOG 0 or 1 ) and receipt of at least two cycles of cisplatin, 
anthracycline and taxane chemotherapy at our center.

The study protocol was approved by the ethics committee (Institutional Review Board) of our institution.

\section{Treatment}

All patients had received cisplatin $60 \mathrm{mg} / \mathrm{m}^{2}$ once in 3 weeks in combination with a taxane (paclitaxel $80 \mathrm{mg} / \mathrm{m}^{2}$ once a week) for 12 weeks. This was preceded or followed by 8 weeks of anthracycline (epirubicin $90 \mathrm{mg} / \mathrm{m}^{2}$ or doxorubicin $60 \mathrm{mg} / \mathrm{m}^{2}$ ) with cyclophosphamide $600 \mathrm{mg} / \mathrm{m}^{2}$ administered every 2 weeks. A cumulative target dose of cisplatin $240 \mathrm{mg} / \mathrm{m}^{2}$ was planned for every patient. Standard intravenous hydration was administered on the days of cisplatin administration. Upon completion of neoadjuvant chemotherapy, patients underwent either mastectomy or breast conservation surgery. Following surgery, patients received standard locoregional radiation therapy. At the discretion of the treating physician, the patients with residual disease, who were deemed to be at high risk for relapse, were treated either with capecitabine or oral metronomic chemotherapy (consisting of cyclophosphamide $50 \mathrm{mg}$ once daily and methotrexate $15 \mathrm{mg}$ once a week) or both.

\section{Outcomes and follow-up}

The primary outcome was the proportion of pathological complete response. The secondary outcomes assessed were tolerability of the regimen, adherence to planned therapy, disease-free survival, overall survival, and the additional effect of oral metronomic chemotherapy.

The pathologist graded the response to chemotherapy, as seen in the surgical specimen, in accordance with the Miller-Payne System [24]. We defined pathological complete response as no residual invasive cancer in the breast or axilla. The adverse events documented in the medical records were assessed and graded for each patient, according to the National Cancer Institute's Common Terminology Criteria for Adverse Events (CTCAE), v5.0. Patient follow-up was accomplished by telephonic interviews. In those who could not be contacted over the telephone, the most recent out-patient visit was taken as the last point of the follow-up.

\section{Statistical analysis}

The Fisher's exact test or chi-square test were used in comparing categorical variables. Survival analysis was done employing the Kaplan-Meier method, and survival curves were compared using the Cox-Mantel log-rank test. We calculated disease-free survival and overall survival from the time of diagnosis. Binary logistic regression was done to identify the factors which influenced $p C R$ rates. A P-value of less than 0.05 was considered statistically significant. Data entry was done using Epi Info v7.2.3.1 and analyzed using IBM SPSS Statistics v23.

\section{Results}

\section{Patient characteristics}

Eighty-three patients with predominantly locally advanced triple-negative breast cancer received neoadjuvant cisplatin-based combination chemotherapy from April 2015 to June 2019. The mean age of the population was 42.56 years (range $20-56$ years). Tab. 1 lists the baseline characteristics of the patients included in the study. The tumor was locally advanced in $79.6 \%$ of patients. The tolerance to cisplatin and weekly paclitaxel after administration of anthracycline and cyclophosphamide was poor, with only $51.8 \%$ of patients completing all the planned cycles of chemotherapy. Breast conservation surgery was performed in $4 \%$ of patients with the majority undergoing mastectomy in view of the large operable or locally advanced disease at presentation. Out of the 83 patients included, six did not undergo surgery at our institution. Oral metronomic chemotherapy (OMCT) was given to $32.5 \%$ of patients. The median duration of OMCT was 6 months (range 1-24 months).

\section{Outcomes}

Pathological complete response in both breast (T0/Tis) and axilla (NO) was observed in $48.1 \%$ of patients (Tab. 2). The Miller Payne grade 5 pathological response was seen in $61 \%$ of patients. Good partial responses (Miller Payne
Tab. 1. Patient and tumor characteristics.

\begin{tabular}{|c|c|c|}
\hline Characteristic & Number & $\%$ \\
\hline Female & 83 & 100 \\
\hline \multicolumn{3}{|l|}{ menopausal status } \\
\hline premenopausal & 51 & 61.5 \\
\hline perimenopausal & 9 & 10.8 \\
\hline postmenopausal & 23 & 27.7 \\
\hline \multicolumn{3}{|l|}{ Performance status } \\
\hline ECOG 0 & 34 & 40.9 \\
\hline ECOG 1 & 49 & 59.0 \\
\hline
\end{tabular}

T stage (clinical)

\begin{tabular}{|l|c|c|}
\hline Tx & 6 & 7.3 \\
\hline T0 & 1 & 1.2 \\
\hline T1 & 1 & 1.2 \\
\hline T2 & 15 & 18.3 \\
\hline T3 & 23 & 28 \\
\hline T4b & 36 & 43.9 \\
\hline
\end{tabular}

N stage (clinical)

\begin{tabular}{c|c|c|}
\hline N0 & 15 & 18.3 \\
\hline N1 & 43 & 52.4 \\
\hline N2 & 22 & 26.8 \\
\hline N3 & 2 & 2.4
\end{tabular}

AJCC stage

\begin{tabular}{l|c|c|}
\hline IA & 1 & 1.3 \\
\hline IIA & 4 & 5.1 \\
\hline IIB & 11 & 14.1 \\
\hline IIIA & 25 & 32.1 \\
\hline IIIB & 35 & 44.9 \\
\hline IIIC & 2 & 2.6
\end{tabular}

\section{Grade of tumor}

\begin{tabular}{|l|c|c|}
\hline grade 1 & 2 & 2.4 \\
\hline grade 2 & 20 & 24.4 \\
\hline grade 3 & 60 & 73.2 \\
\hline
\end{tabular}

\section{Histopathology of tumor}

\begin{tabular}{l|c|c|}
\hline ductal carcinoma & 79 & 95.2 \\
\hline metaplastic carcinoma & 3 & 3.6 \\
\hline apocrine carcinoma & 1 & 1.2
\end{tabular}

\section{Type of surgery}

breast conservation mastectomy

34

AJCC - American Joint Committee on Cancer, ECOG - Eastern Cooperative Cancer Group 
Tab. 2. Pathological response.

\begin{tabular}{|c|c|c|}
\hline $\begin{array}{l}\text { Pathological } \\
\text { response }(\mathrm{N}=77)\end{array}$ & $\%$ & $\mathbf{N}$ \\
\hline \multicolumn{3}{|l|}{ уртO NO } \\
\hline yes & 42.9 & 33 \\
\hline no & 57.1 & 44 \\
\hline \multicolumn{3}{|l|}{ ypTO/is NO } \\
\hline yes & 48.1 & 37 \\
\hline no & 51.9 & 40 \\
\hline $\begin{array}{l}\text { Breast pCR } \\
\text { (ypTo/is NO/+) }\end{array}$ & 61.0 & 47 \\
\hline nodal pCR (ypNo) & 66.2 & 51 \\
\hline \multicolumn{3}{|l|}{ Miller Payne } \\
\hline Miller Payne grade 1 & 5.2 & 4 \\
\hline Miller Payne grade 2 & 1.3 & 1 \\
\hline Miller Payne grade 3 & 13.0 & 10 \\
\hline Miller Payne grade 4 & 19.5 & 15 \\
\hline Miller Payne grade 5 & 61.0 & 47 \\
\hline \multicolumn{3}{|c|}{$\begin{array}{l}\mathrm{pCR} \text { - pathological complete } \\
\text { response }\end{array}$} \\
\hline
\end{tabular}

grades 3 and 4) were observed in $32.5 \%$ of patients.

On binary logistic regression analysis, among the possible factors which could have influenced $\mathrm{pCR}$ rates (performance status, menopausal status, number of planned chemotherapy cycles completed, clinical stage, histopathology of tumor, grade of tumor), a higher percentage of planned cycles of chemotherapy completed was significantly associated with a higher chance of pCR with an odds ratio of 1.044 (95\% Cl 1.004-1.086; $P=0.03$ ).

The median duration of follow up was 24 months (range 2-55 months). The overall survival at 1 and 3 years was $96.1 \%$ and $78.8 \%$, respectively. The overall survival at 1 and 3 years was $96.4 \%$ and $83.5 \%$ for those who had a pCR, respectively and $97.4 \%$ and $82.4 \%$ for those who did not have $\mathrm{pCR}$, respectively. The median survival time was not reached. The disease-free survival at 1 and 3 years was $93.3 \%$ and $65.2 \%$, respectively. Specifically, the disease-free survival at 1 and 3 years was $96.7 \%$ and $77.6 \%$ for those who had a $\mathrm{pCR}$, respec- tively, and $92.3 \%$ and $62.7 \%$ for those who did not have $\mathrm{pCR}$, respectively (Fig. 1). The log-rank test did not show any statistically significant difference in the survival curves for those patients with and without $\mathrm{pCR}$.

The disease-free survival at 1 year was 91\% for those who received OMCT and $88 \%$ for those who did not receive OMCT. Among those who did not achieve $\mathrm{pCR}$, the proportion surviving disease-free at 1 year was $94 \%$ for those who received OMCT in comparison to $81 \%$ for those who did not receive OMCT. There was no statistically significant (log-rank test) difference in survival between either of these two groups.

\section{Adverse events}

The most common treatment-related adverse events observed were hematological, with anemia being the most frequent one (Tab. 3). Overall, 95.2\% of patients developed anemia, with $38 \%$ being grade $3 / 4$. The incidence of thrombocytopenia was $45.7 \%$, with the majority being grade 1 . Over the scheduled course of chemotherapy, $51.7 \%$

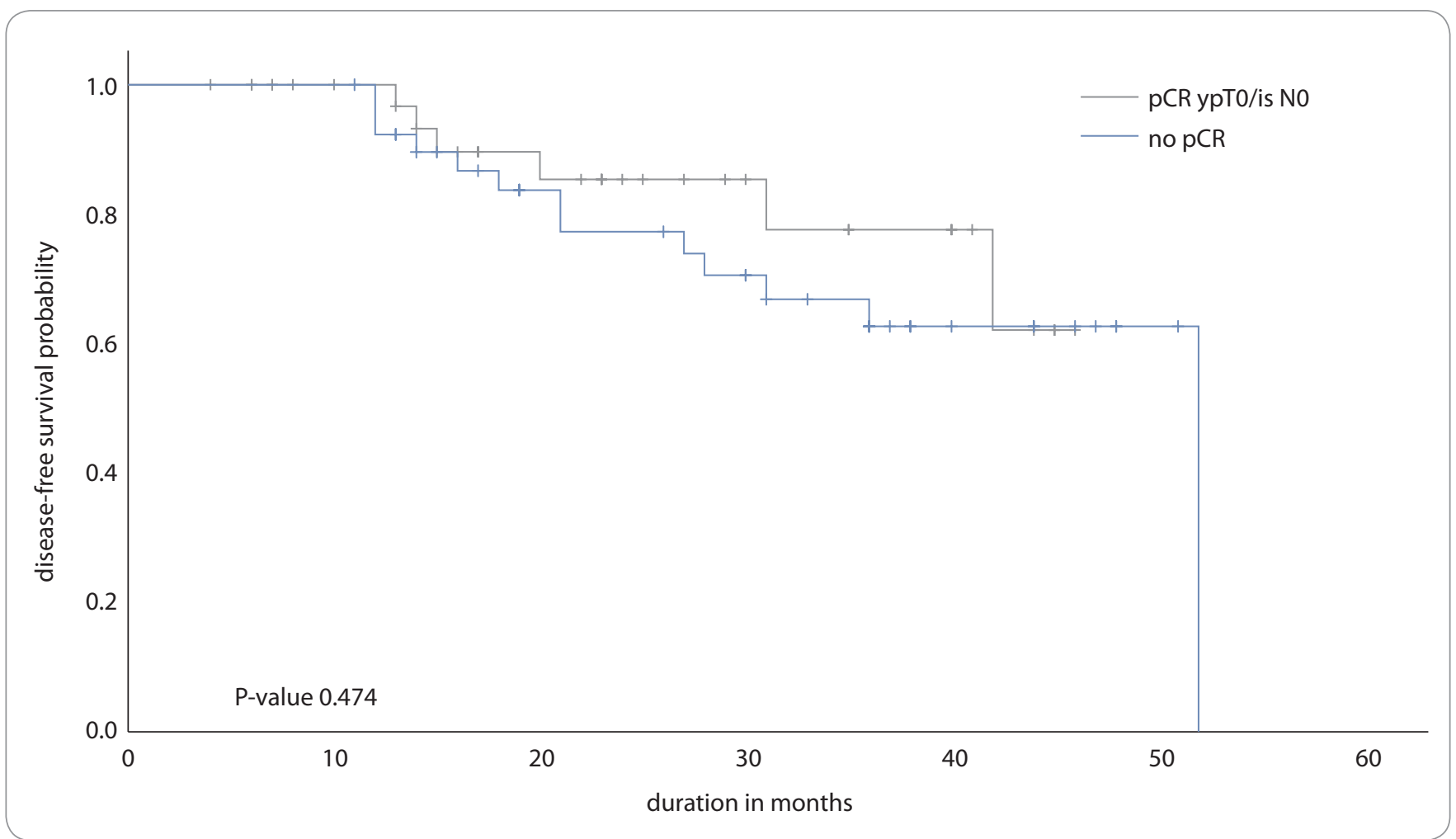

Fig. 1. The disease-free survival.

pCR - pathological complete response 
had neutropenia, with $21 \%$ being grade 4. Six patients $(7 \%)$ were admitted with febrile neutropenia. One of them presented with septic shock and required intensive care.

Five patients $(6 \%)$ had mild to moderate acute kidney injury, probably cisplatin-induced, all of whom recovered promptly and did not require cessation of chemotherapy. Cisplatin had to be discontinued in two patients after they developed hearing loss, with the audiogram showing a sensorineural pattern.

Chemotherapy-induced nausea and vomiting, mostly of grade 1, occurred in $18 \%$ of the patients. Peripheral neuropathy occurred in 10 patients. The rate of infections was $18 \%$, with superficial skin and subcutaneous infections being the most common one.

Other, less commonly observed adverse effects were fatigue, myalgia, mucositis, and diarrhea, none of which were severe enough to warrant an admission or interruption of chemotherapy. There was no treatment-related mortality.

\section{Discussion}

Indian women have a higher incidence of locally advanced breast cancer at presentation to their oncologist as compared to the women from developed countries [2]. This is due to the lack of screening in the community, low awareness, and lack of access to well-equipped diagnostic centers, which, in turn, contributes to poor outcomes $[25,26]$. With the currently available treatment options, outcomes remain poor in this population [11]. The incorporation of carboplatin has improved response rates and outcomes in some studies $[14,15,27]$. Cisplatin may be equally effective and less myelotoxic than carboplatin. Our study reports the feasibility, outcomes, and toxicity observed in a developing country with the use of cisplatin in operable TNBC.

The $\mathrm{pCR}$ rates achieved with carboplatin in the GeparSixto phase II trial of 296 patients with early breast cancer (predominantly smaller tumors and node-negative) was 53.2\% [15]. The pCR rate reported by Hurley et al in 144 patients comparing carboplatin and cisplatin in neoadjuvant therapy of locally

Tab. 3. Adverse events.

\begin{tabular}{|l|c|c|c|}
\hline Adverse event & $\begin{array}{c}\text { Grade 1/2 } \\
\text { \% (N) }\end{array}$ & $\begin{array}{c}\text { Grade 3 } \\
\text { \% (N) }\end{array}$ & $\begin{array}{c}\text { Grade 4 } \\
\text { \% (N) }\end{array}$ \\
\hline anemia & $60.3(50)$ & $32.5(27)$ & $2.4(2)$ \\
\hline thrombocytopenia & $36.1(30)$ & $8.4(7)$ & $2.4(2)$ \\
\hline neutropenia & $32.8(27)$ & $7.2(6)$ & $21.7(18)$ \\
\hline febrile neutropenia & - & $6(5)$ & $1.2(1)$ \\
\hline acute kidney injury & $6(5)$ & - & - \\
\hline nausea and vomiting & $15.6(13)$ & $2.4(2)$ & - \\
\hline myalgia & $3.6(3)$ & - & - \\
\hline hearing loss & - & $2.4(2)$ & - \\
\hline anaphylaxis/allergy & - & $1.2(1)$ & - \\
\hline peripheral neuropathy & $7(6)$ & $4.8(4)$ & - \\
\hline rash & $1.2(1)$ & - & - \\
\hline
\end{tabular}

advanced TNBC (97 cisplatin, 47 carboplatin) was higher with cisplatin (36\%) as compared to the carboplatin arm (21\%). They also reported that the disease-free survival and overall survival was significantly better with cisplatin as compared to carboplatin [18]. Frasci et al reported $\mathrm{pCR}$ (pT0/is, N0) rates of $62 \%$ in a phase II trial of 74 patients with a neoadjuvant chemotherapy regimen consisting of paclitaxel, epirubicin, and weekly cisplatin [23]. Huang et al retrospectively studied 145 patients who received neoadjuvant platinum (52 cisplatin, 93 carboplatin). They reported a higher pCR rate with cisplatin as compared to carboplatin (44 vs. $42 \%$ ); however, the difference did not reach the statistical significance [17]. Smaller phase II trials of cisplatin have reported $\mathrm{pCR}$ rates varying from 17 to $56 \%$ [28-32].

A meta-analysis of platinum in TNBC, which included 8 carboplatin trials and 1 cisplatin trial concluded that platinum significantly increased $\mathrm{pCR}$ rates (OR 2.12; 95\% Cl 1.64-2.73; $P<0.001$ ) [33]. Another meta-analysis reached similar conclusions with an odds ratio of pCR being 3.32 (95\% Cl 2.39-4.61; $\mathrm{P}<0.0001)$ with platinum-containing regimens as compared to non-platinum regimens [34].

Patients with locally advanced disease constituted only a small proportion of the studies mentioned above. Our study differs in that most patients had larger tumors (a large percentage of T4b, Tab. 1) and were node-positive. The pCR rate seen in our study was similar to that reported by Jovanović et al, i.e. 48\% [35]. The patients who tolerated and managed to complete a higher percentage of chemotherapy cycles as planned had a significantly higher rate of $\mathrm{pCR}$.

The follow-up duration for our study was short, with a median follow-up time of 2 years. There is a paucity of Indian survival data for triple-negative breast cancer, specifically for locally advanced disease. An eight-year followup of 148 patients from a cancer center in New Delhi reported a disease-free survival of $56 \%$ for locally advanced disease, which dropped to $34 \%$ with axillary involvement [11]. Platinum was not used in these earlier studies. These patients had received both neoadjuvant and adjuvant chemotherapy; the details of the regimen used was not provided. The disease-free survival and overall survival at 3 years in our study was $65 \%$ and $78 \%$, respectively. This improvement in outcomes with cisplatin is encouraging, despite having a population who were not detected by screening, with large tumors and involved axillary nodes. Our survival outcomes with cisplatin are similar to those reported by Hurley et al. With a median follow up of 4 years, they reported progression-free survival 
of $60 \%$ and overall survival of $70 \%$ at 3 years. The grade 3/4 adverse events were predominantly hematological and were manageable in a resource-limited setting. Thrombocytopenia was grade $3 / 4$ in $10.8 \%$ of patients, with none developing bleeding manifestations or requiring platelet transfusions [18]. In the Geparsixto trial, Minckwitz et al reported grade $3 / 4$ thrombocytopenia rates of $14 \%$ [15]. Grade 3/4 anemia was seen in $34.9 \%$ of our patients, in comparison to $15.3 \%$ of grade $3 / 4$ anemia reported by Minckwitz et al [15].

Acute kidney injury in this study, which occurred in $6 \%$ of patients, was probably cisplatin-induced. All of them recovered promptly with i.v. hydration and did not require cessation of chemotherapy. The incidence of grade 3/4 neutropenia was $29 \%$, and febrile neutropenia was seen in $7 \%$ of patients. This is in contrast to the grade 3 or 4 neutropenia seen in $65 \%$ of patients and febrile neutropenia seen in $8.5 \%$ of patients who were in the carboplatin arm in the GeparSixto trial [15]. Clinically significant grade $2 / 3$ neuropathy was reported in $11.8 \%$ of patients in our study, which was higher than the $6 \%$ of grade 3 sensory neuropathy seen with carboplatin in the GeparSixto data. In our analysis, only $51 \%$ of patients could complete all planned chemotherapy cycles.

There is limited information available on cisplatin in early TNBC with most other trials preferring carboplatin. Our study provides information on the utility and tolerance of cisplatin. This study has limitations as it is a retrospective analysis. However, the results indicate its efficacy and warrant further studies (phase III trials) to establish the possible role of cisplatin over carboplatin as the preferred platinum in neoadjuvant therapy for triple-negative breast cancer.

\section{Conclusions}

In this retrospective study, the addition of cisplatin to standard neoadjuvant chemotherapy with anthracycline and taxane in triple-negative breast cancer resulted in high pathological complete response rates, albeit with moderate but manageable hematological toxicity. The administration of this regimen is feasible in resource-limited settings as well, which can lead to better responses even in patients who present with locally advanced disease and, thus, possibly lead to better outcomes.

\section{Acknowledgments}

We wish to thank our patients who consented to undergo this regimen of chemotherapy and be a part of this study.

\section{Compliance with ethical standards}

The study protocol was approved by the ethics commit tee (Institutional Review Board, The Office of Research, Christian Medical College, Vellore, India) of our institution prior to the commencement of the retrospective review. The study was performed in accordance with the ethical standards as laid down in the WMA Declaration of Helsinki (adopted by the $18^{\text {th }}$ WMA General Assembly, Helsinki, Finland, June 1964 and amended by the 64th WMA General Assembly, Fortaleza, Brazil, October 2013). Informed consent was waived by the institutional review board as this was a retrospective study based on data obtained from medical records.

\section{Funding sources}

This study did not receive any specific grant from funding agencies in the public, commercial, or not-profit sectors.

\section{Credit author statement}

Josh Thomas Georgy: conceptualization, methodology, formal analysis, investigation, writing - original draft, visualization

Ashish Singh: conceptualization, methodology, formal analysis, investigation, writing - review \& editing, visualization, supervision, project administration, funding acquisition Ajoy Oommen John: conceptualization, methodology, formal analysis, writing - review \& editing, visualization Anjana Joel: conceptualization, methodology, forma analysis, investigation, writing - review \& editing, visualization, supervision

Anand George Andrews: Investigation, formal analysis Divya Bala Thumaty: conceptualization, methodology, formal analysis, investigation, writing - review \& editing visualization

Grace Rebekah: formal analysis, data curation, software Elanthenral Sigamani: methodology, formal analysis, investigation, writing - review \& editing, visualization Jagan Chandramohan: methodology, formal analysis, investigation, writing - review \& editing, visualization Marie Therese Manipadam: methodology, formal analysis, investigation, writing - review \& editing, supervision visualization

Anish Jacob Cherian: methodology, formal analysis, investigation, writing - review \& editing, visualization Deepak Thomas Abraham: methodology, formal analysis, investigation, writing - review \& editing, visualization Paul M J: methodology, formal analysis, investigation writing - review \& editing, visualization

Rajesh Balakrishnan: methodology, formal analysis, investigation, writing - review \& editing, visualization Selvamani Backianathan: methodology, formal analysis, investigation, writing - review \& editing, visualization Raju Titus Chacko: writing - review \& editing, supervision project administration, funding acquisition, resources

\section{References}

1. Ferlay J, Ervik M, Lam F et al. Global Cancer Observatory: Cancer Today [online]. Available from: https://gco. iarc.fr/today/home.
2. Malvia S, Bagadi SA, Dubey US et al. Epidemiology of breast cancer in Indian women. Asia Pac J Clin Oncol 2017: 13(4): 289-295. doi: 10.1111/ajco.12661.

3. Leong SPL, Shen Z-Z, Liu T-J et al. Is breast cancer the same disease in asian and western countries? World J Surg 2010; 34(10): 2308-2324. doi: 10.1007/s00268-0100683-1.

4. Sandhu GS, Erqou S, Patterson $\mathrm{H}$ et al. Prevalence of triple-negative breast cancer in india: systematic review and meta-analysis. J Glob Oncol 2016; 2(6): 412-421. doi: 10.1200/JGO.2016.005397.

5. Foulkes WD, Smith IE, Reis-Filho JS. Triple-negative breast cancer. N Engl J Med 2010; 363(20): 1938-1948. doi: 10.1056/NEJMra1001389.

6. Ishitha G, Manipadam MT, Backianathan S et al. Clinicopathological study of triple negative breast cancers. J Clin Diagn Res 2016; 10(9): EC05-09. doi:10.7860/JCDR/2016 /20475.8539

7. Abramson VG, Lehmann BD, Ballinger TJ et al. Subtyping of triple-negative breast cancer: implications for therapy: subtyping triple-negative breast cancer. Cancer 2015; 121(1): 8-16. doi:10.1002/cncr.28914.

8. Anders C, Carey LA. Understanding and treating triplenegative breast cancer. Oncology (Williston Park) 2008; 22(11): 1233-1243.

9. Bianchini G, Balko JM, Mayer IA et al. Triple-negative breast cancer: challenges and opportunities of a heterogeneous disease. Nat Rev Clin Oncol 2016; 13(11): 674690. doi: 10.1038/nrclinonc.2016.66.

10. Allemani C, Weir HK, Carreira H et al. Global surveillance of cancer survival 1995-2009: analysis of individual data for 25676887 patients from 279 population-based registries in 67 countries (CONCORD-2). Lancet 2015; 385(9972): 977-1010. doi:10.1016/S0140-6736(14)62 038-9.

11. Chandra D, Suresh P, Sinha R et al. Eight year survival analysis of patients with triple negative breast cancer in India. Asian Pac J Cancer Prev 2016: 17(6): 2995-2999.

12. von Minckwitz G, Untch M, Blohmer J-U et al. Definition and impact of pathologic complete response on prognosis after neoadjuvant chemotherapy in various intrinsic breast cancer subtypes. J Clin Oncol 2012; 30(15): 1796-1804. doi: 10.1200/JCO.2011.38.8595.

13. Cortazar P, Zhang L, Untch M et al. Pathological complete response and long-term clinical benefit in breast cancer: the CTNeoBC pooled analysis. The Lancet 2014: 384(9938): 164-172. doi: 10.1016/S0140-6736(13)62 $422-8$

14. Sikov WM, Berry DA, Perou CM et al. Impact of the addition of carboplatin and/or bevacizumab to neoadjuvant once-per-week paclitaxel followed by dose-dense doxorubicin and cyclophosphamide on pathologic complete response rates in stage II to III triple-negative breast cancer: CALGB 40603 (Alliance). JCO 2015; 33(1): 13-21. doi: 10.1200/JCO.2014.57.0572.

15. von Minckwitz G, Schneeweiss A, Loibl S et al. Neoadjuvant carboplatin in patients with triple-negative and HER2-positive early breast cancer (GeparSixto; GBG 66): a randomised phase 2 trial. Lancet Oncol 2014; 15(7): 747-756. doi: 10.1016/S1470-2045(14)70160-3.

16. Yerushalmi R, Hayes MM, Gelmon KA et al. A phase II trial of a neoadjuvant platinum regimen for locally advanced breast cancer: pathologic response, long-term follow-up, and correlation with biomarkers. Clin Breast Cancer 2009: 9(3): 166-172. doi: 10.3816/CBC 2009 n.027. 17. Huang L, Liu Q, Chen S et al. Cisplatin versus carboplatin in combination with paclitaxel as neoadjuvant regimen for triple negative breast cancer. Onco Targets Ther 2017; 10: 5739-5744. doi: 10.2147/OTT.S145934. 18. Hurley J, Reis IM, Rodgers SE et al. The use of neoadjuvant platinum-based chemotherapy in locally advanced breast cancer that is triple negative: retrospective analysis of 144 patients. Breast Cancer Res Treat 2013; 138(3): 783794. doi: 10.1007/s10549-013-2497-y. 
19. Frolova M, Ignatova E, Glazkova E et al. Neoadjuvant chemotherapy with dose-dense doxorubicin, cisplatin and paclitaxel in patients with early triple-negative breast cancer (TNBC). JCO 2015; 33 (15_suppl): 1074-1074. doi: 10.1200/jco.2015.33.15_suppl.1074.

20. du Bois A, Lück H-J, Meier W et al. A Randomized clinical trial of cisplatin/paclitaxel versus carboplatin/paclitaxel as first-line treatment of ovarian cancer. J Natl Cancer Inst 2003; 95(17): 1320-1329. doi: 10.1093/jnci/djg 036.

21. Chan JK, Brady MF, Penson RT et al. Weekly vs. every3-week paclitaxel and carboplatin for ovarian cancer. New Engl J Med 2016; 374(8): 738-748. doi: 10.1056/ NEJMoa1505067.

22. Lück H-J, Roché H. Weekly paclitaxel: an effective and well-tolerated treatment in patients with advanced breast cancer. Crit Rev Oncol/Hematol 2002; 44: 15-30. doi: 10.1016/S1040-8428(02)00105-1.

23. Frasci G, Comella P, Rinaldo M et al. Preoperative weekly cisplatin-epirubicin-paclitaxel with G-CSF support in triple-negative large operable breast cancer. Ann Oncol 2009; 20(7): 1185-1192. doi: 10.1093/annonc/mdn748.

24. Ogston KN, Miller ID, Payne S et al. A new histological grading system to assess response of breast cancers to primary chemotherapy: prognostic significance and survival. Breast 2003; 12(5): 320-327. doi: 10.1016/S09609776(03)00106-1.

25. Gupta A, Shridhar K, Dhillon PK. A review of breast cancer awareness among women in India: Cancer liter- ate or awareness deficit? Eur J Cancer 2015; 51(14): 20582066. doi: 10.1016/j.ejca.2015.07.008.

26. Gadgil A, Sauvaget C, Roy N et al. Breast cancer awareness among middle class urban women - a community-based study from Mumbai, India. Asian Pac J Cancer Prev 2015; 16(15): 6249-6254. doi: 10.7314/apjcp.2015.16.15.6249.

27. Loibl S, Weber KE, Timms KM et al. Survival analysis of carboplatin added to an anthracycline/taxane-based neoadjuvant chemotherapy and HRD score as predictor of response - final results from GeparSixto. Annals of Oncology 2018; 29(12): 2341-2347. doi: 10.1093/annonc/mdy460.

28. Sirohi B, Arnedos M, Popat S, et al. Platinum-based chemotherapy in triple-negative breast cancer. Ann Oncol 2008; 19(11): 1847-1852. doi: 10.1093/annonc/ mdn395.

29. Torrisi R, Balduzzi A, Ghisini R et al. Tailored preoperative treatment of locally advanced triple negative (hormone receptor negative and HER2 negative) breast cancer with epirubicin, cisplatin, and infusional fluorouraci followed by weekly paclitaxel. Cancer Chemother Pharmacol 2008; 62(4): 667-672. doi: 10.1007/s00280-0070652-z.

30. L-TweigeriTA, AlSayed A, Alawadi S et al. A multicenter prospective phase II trial of neoadjuvant epirubicin, cy clophosphamide, and 5-fluorouracil (FEC100) followed by cisplatin-docetaxel with or without trastuzumab in locally advanced breast cancer. Cancer Chemother Pharmaco 2016; 77(1): 147-153. doi: 10.1007/s00280-015-2906-5.
31. Ferreira AR, Metzger-Filho O, Sarmento RM et al. Neoadjuvant treatment of stage IIB/III triple negative breast cancer with cyclophosphamide, doxorubicin, and cisplatin (CAP Regimen): a single arm, single center phase II Study (GBECAM 2008/02). Front Oncol 2017; 7: 329. doi: 10.3389/fonc.2017.00329

32. Cancello G, Bagnardi V, Sangalli C et al. Phase II study with epirubicin, cisplatin, and infusional fluorouracil followed by weekly paclitaxel with metronomic cyclophosphamide as a preoperative treatment of triple-negative breast cancer. Clin Breast Cancer 2015; 15(4): 259-265. doi: 10.1016/j.clbc.2015.03.002.

33. Wang D, Feng J, Xu B. A meta-analysis of platinumbased neoadjuvant chemotherapy versus standard neoadjuvant chemotherapy for triple-negative breast cancer. Future Oncol 2019; 15(23): 2779-2790. doi: 10.2217/fon-2019-0165.

34. Petrelli F, Coinu A, Borgonovo K et al. The value of platinum agents as neoadjuvant chemotherapy in triple-negative breast cancers: a systematic review and meta-analysis. Breast Cancer Res Treat 2014; 144(2): 223-232. doi: 10.1007/s10549-014-2876-z

35. Jovanović B, Mayer IA, Mayer EL et al. A randomized phase II neoadjuvant study of cisplatin, paclitaxel with or without everolimus in patients with stage II/III triple-negative breast cancer (TNBC): responses and long-term outcome correlated with increased frequency of DNA damage response gene mutations, TNBC subtype, AR status, and Ki67. Clin Cancer Res 2017; 23(15): 4035-4045. doi: 10.1158/1078-0432.CCR-16-3055. 